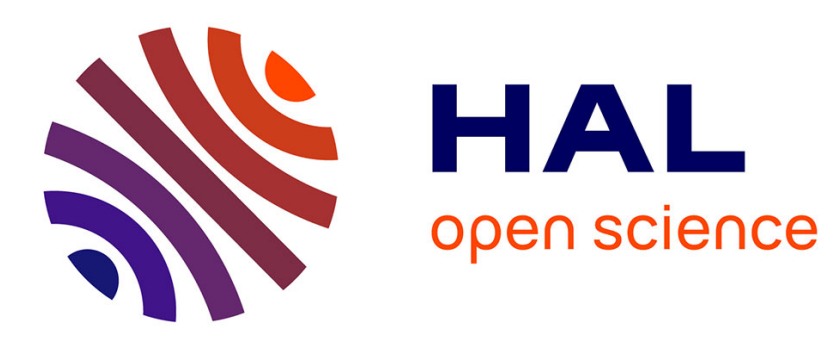

\title{
Combining a closed and open border in the terrorism era: the example of the Canada/US border
}

\author{
Pierre-Alexandre Beylier
}

\section{To cite this version:}

Pierre-Alexandre Beylier. Combining a closed and open border in the terrorism era: the example of the Canada/US border. Reading(s) / Across / Border, 2020. hal-03132451

\section{HAL Id: hal-03132451 \\ https://hal.science/hal-03132451}

Submitted on 5 Feb 2021

HAL is a multi-disciplinary open access archive for the deposit and dissemination of scientific research documents, whether they are published or not. The documents may come from teaching and research institutions in France or abroad, or from public or private research centers.
L'archive ouverte pluridisciplinaire HAL, est destinée au dépôt et à la diffusion de documents scientifiques de niveau recherche, publiés ou non, émanant des établissements d'enseignement et de recherche français ou étrangers, des laboratoires publics ou privés. 


\title{
Combining a closed and open border in the terrorism era: the example of the Canada/US border
}

\author{
Pierre-Alexandre BEYLIER \\ Université Grenoble-Alpes
}

In the last few years, with the different terrorist attacks that have hit several European countries and the so-called «migrant crisis » with which the European Union is struggling, arguments calling for the reinforcement of border controls have multiplied exponentially in the political arena. From a North American perspective, the development of such a rhetoric is anything but new. The United States and its two land neighbors - Canada and Mexico - have been confronted to similar issues since 2001 and the terrorist attacks that saw four planes crash into the World Trade Center, the Pentagon and Pennsylvania.

In the 1990s, a number of analysists considered that the world had reached "the end of history" and that, as a result, borders were no longer relevant ${ }^{1}$. This phenomenon was due to the end of the Cold War that marked the consecration of the capitalist model, thus contributing to the rise of a "borderless world". Borders "opened up" to promote international trade, the free flow of capitals and, to a lesser extent, of people. Regional agreements of integration multiplied - with MECOSUR, NAFTA in the Americas - and supranational organizations - such as the European Union, which is the most advanced model of economic and political integration - took momentum. Even if the ambivalence of borders that are at the same time separating lines and meeting places is a well-knwon fact that is well-documented ${ }^{3}$, this new context saw borders assume less the role of an obstacle and more the role of a dynamic interface. As a result, borders were defunctionalized: most traditional functions as defined by Michel Foucher ${ }^{4}$ - a strategic/defensive function, a commercial function, a migratory function - were less present to facilitate the flow of goods, capitals and people. However, this process of "debordering" only

\footnotetext{
${ }^{1}$ Fukuyama, Francis, The End of History and the Last Man, New York City, Free Press, 1992.

${ }^{2}$ Ohmae, Kenichi, The Borderless World - Power and Strategy in the Global Market Place, New York Coty, Harper and Collins, 1990.

${ }^{3}$ Pradeau, Christian, Jeux et enjeux des frontières, Bordeaux, Presses Universitaires de Bordeaux, 1994, p. 5 ; Courlet, Claude, “La frontière : couture ou coupure ?’, Economie et Humanisme, 1988, p. 301.

${ }^{4}$ In addition to these three functions, he also defined a political/ideological function and an ethnic/cultural function (cf. Foucher Michel, Fronts et Frontières, Paris, Fayard, 1991, p. 39).
} 
prevailed for a while and it soon happened simultaneously as that of rebordering ${ }^{5}$, with the reinforcement of border enforcement and the construction of fences and walls in the 1990s and even more so after $9 / 11$.

Interestingly enough, the Canada/US border in particular experienced these phenomena. Known for over one century as the "longest undefended border in the world", it was an "open border" that was barely monitored. Controls were brief and people could cross it very quickly ${ }^{6}$. It was a mere "administrative inconvenience", its strategic and migratory functions being almost absent. Based on this openness, the two North American neighbors had developed a close relationship and cross-border ties were at once numerous and diverse, especially after the adoption of the Canada/US Free Trade Agreement in 1988, expanded in 1992 with the North American Free Trade Agreement that defunctionalized the commercial function of the border. First of all, in 2000, Canada and the United States shared the largest trade relationship in the world, worth 588 billion dollars ${ }^{8}$. Secondly, over 1.3 million people crossed it yearly, 2/3 of whom for same-day travels ${ }^{9}$. Finally, in a less visible way, the border was crossed by investments ${ }^{10}$. The consequence was that the two countries were highly interdependent and integrated $^{11}$. For instance, beyond just being each other's top trading partners, both countries played a central role in each other's economy: over $82 \%$ of Canadian exports went to the US in

\footnotetext{
${ }^{5}$ Lybecker, L. Donna, "The Policy of Border Fencing between the United States and Mexico: Permeability and Shifting Fuctions", in The Journal of Southwest, 50, 3 (Autumn 2008), p. 337.

${ }^{6}$ Andreas, Peter, The Rebordering of North America: Integration and Exclusion in a New Security Context, New York, Routledge, 2003, p. 10.

${ }^{7}$ Daniel Drache, Borders Matters: Homeland Security and the Search for North America, Halifax, Fernwood, 2004, p. 35 .

${ }^{8}$ Statistique Canada, « Tableau 228-0003 - Importations et exportations de marchandises, par groupes principaux et par marchés pour tous les pays », Ottawa, Statistique Canada <http://www5.statcan.gc.ca/cansim/a26> (consulté le 14 mai 2013).

9 NATC, "Canada/United States Travel by Mode of Transportation", <http://nats.sct.gob.mx/go-to-tables/table-9north-american-passenger-travel/table-9-1b-canada-united-statesunited-states-canada-travel-by-mode-oftransportation/> (accessed on October 12, 2016).

${ }^{10}$ Department of Foreign Affairs and International Trade, "Canada's FDI_stocks-Outward_by_Country-FRA", 〈http://www.international.gc.ca/economist-economiste/assets/pdfs/FDI_stocks-Outward_by_Country-FRA.pdf> (accessed on July 13, 2011).

${ }^{11}$ Carroué, Laurent ans Collet, Didier, Canada, Etats-Unis, Mexique - un ancien nouveau monde, Paris, Editions Bréal, 2012, p. 184.
} 
$2000-23 \%$ of American exports went to Canada ${ }^{12}$ - and 33\% of Canada's GDP was dependent on its exports to its southern neighbor ${ }^{13}$.

However, when 9/11 occurred, not only did this "defunctionalized" open border ${ }^{14}$ begin to draw the attention of both politicians and the media but it also fueled concerns ${ }^{15}$. In substance, it was described as a "porous" border, which was under-defended and thus vulnerable since it could be exploited by potential terrorists to launch a terrorist attack in the US. A specific rhetoric was therefore developed in order to depict the Canada/US border as the "weak link" in the North American defense system in order to call for its reinforcement ${ }^{16}$. A number of articles were written to accuse the northern border of being responsible for the attacks - although it was later proven that it was not the case - such as «Terrorists Aided by a Leaky US-Canada Line » in The Christian Science Monitor ${ }^{17}$, «Few Resources Spent Guarding Canada Border », The Seattle Times $^{18}$.

As a consequence, the $9 / 11$ terrorist attacks threw North America in a logic of "reassertion of borders ${ }^{19}$," what English-speaking authors call a "rebordering" phenomenon ${ }^{20}$. In the case of the Canada/US border, it did not lead to the construction of real a visible fence contrary to what happened along the Mexico/US border - but to a "securitization" of the international boundary thus plunging the continent in a "re-territorialization" phenomenon that has been taking huge momentum in the last 26 years not just in North America but also in the world $^{21}$. This U-turn is terms of policy is well documented by researchers. All of them point out

\footnotetext{
${ }^{12}$ Clarkson, Stephen, "The View from the Attic", in Peter Andreas, The Rebordering of North America: Integration and Exclusion in a New Security Context, New York, Routledge, 2003, p. 69.

${ }^{13}$ Burleton, Derek, "Canada's Declining Reliance on the US - Where to Grow from Here?", TD Canada, 2012, <http://www.td.com/document/PDF/economics/special/dp0212_trade.pdf> (accessed on September 14, 2012), p. 1.

${ }^{14}$ Pradeau, Christian, Jeux et enjeux des frontières, Bordeaux, Presses Universitaires de Bordeaux, 1994, p. 106.

${ }^{15}$ Concerns had already been expressed at the end of the 1990's and more specifically in 1999 when Ahmed Ressam was apprehended between British Columbia and Washington State while driving a car full of explosive materials.

${ }^{16}$ David, Charles-Phillipe, Le 11 Septembre 2001, cinq ans plus tard: Le terrorisme, les Etats-Unis et le Canada, Québec, Septentrion, 2006, p. 91.

${ }^{17}$ Clayton, Mark, "Terrorists Aided by a Leaky US-Canada Line", The Christian Science Monitor, September 19, 2001.

${ }^{18}$ Neff, James et al, "Few Resources Spent Guarding Canada Border", The Seattle Times, September 23, 2001.

${ }^{19}$ Foucher, Michel, Le Retour des Frontières, Paris, CNRS Editions, 2016, p. 16.

${ }^{20}$ Popescu, Gabriel, Bordering and Ordering the Twenty-first Century: Understanding Borders, Plymouth, Rowman and Littlefield Publishers Inc., 2011, p 3 et Andreas, Peter, 2003, op. cit..

${ }^{21}$ Valet, Elisabeth, Borders, Fences and Walls - State of Insecurity?, New York, Routledge, 2014, p. 3.
} 
the reinforcement of security at the border by the Bush administration ${ }^{22}$ the fact that border

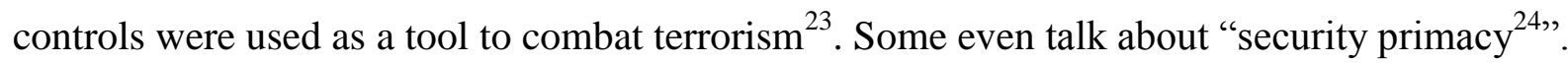

But this new paradigm was at cross purposes with what had dominated so far. Indeed, globalization had triggered a particular phenomenon: that of "de-functionalizing borders" ${ }^{25}$ " that is to say making them more open, removing obstacles to cross-border flows in order to speed up international exchanges and, ultimately, fuel economic growth ${ }^{26}$. However, this logic was questioned overnight when 9/11 occurred insofar as the terrorist threat had used that very same openness, thus making borders the vector of economic prosperity but also vectors of the terrorist

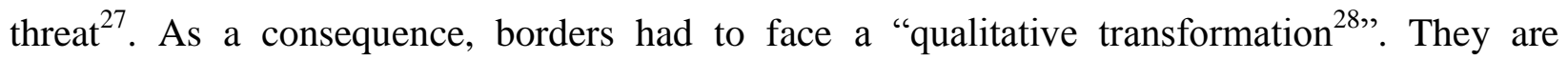
traditionally analyzed and comprehended through a dialectic - open border vs. close border, separation vs. link. However, this transformation consisted in overcoming this traditional binary way of thinking borders ${ }^{29}$, which was "ill-adapted to the challenges of globalization" 30 ".

It was the enterprise that Canada and the US undertook in the wake of 9/11. They set off to reconceptualize their shared border and put in place what they called the "smart border". Depicted by Homeland Security Advisor Tom Ridge as the "border of the future ${ }^{31 ",}$, the main objective was to grasp security and trade/access as mutually not exclusive, an expression that has been relentlessly emphasized in political speeches since $2001^{32}$.

This paper aims at analyzing how the two North American neighbors securitized their territories by putting in place the smart border, a new kind of border with a specific way of functioning that overcomes the traditional binary logic of borders. To that purpose, the two founding agreements that allowed Canada and the US to implement this vision will be studied -

\footnotetext{
${ }^{22}$ David, Charles Phillipe, 2006, op. cit., pp. 95-98.

${ }^{23}$ Alden, Edward, The Closing of the American Border, New York, HarperCollins, 2008, p. 263.

${ }^{24}$ Konrad ,Victor, "Borders, Bordered Lands and Borderlands: Geographical State of Insecurity between Canada and the United States and the Impacts of Security Primacy" in Vallet Elisabeth, Border, Fences and Walls: State of Insecurity?, New York, Routledge, 2014, p. 85.

${ }^{25}$ Pradeau, Christian, 1996, op. cit., p 106.

${ }^{26}$ Douzet, Frédéric and Giblin, Béatrice, Des frontières indépassables ?: Des frontières d'État aux frontières urbaines, Paris, Armand, Colin, 2013, p. 16.

${ }^{27}$ Hart, Gary and Rudman, Warren, Road Map for National Security: Imperative for Change, Washington, United States Commission on National Security/21st Century, 2001, p. 18 et Sloan, Elinor C., Security and Defence in the Terrorist Era: Canada and North America, Montreal, McGill-Queen's University Press, 2005, p. 10.

${ }^{28}$ Popescu, Gabriel, 2011, op. cit., p. 3.

29 Gonin, Patrick, «Frontières Impossibles », in Bouquet, Christian and Velasco-Graciet, Hélène, Regards Géopolitiques sur les Frontières, Paris, L’Harmattan, 2007, pp. 100-101.

${ }^{30}$ Jean-Jacques Roche quoted by Gonin, in Ibid, p. 108.

${ }^{31}$ Tom Ridge quoted by Alden, 2008, op. cit., p. 137.

${ }^{32}$ Andreas, Peter, 2003, op. cit., p 11.
} 
the Smart Border Agreement of 2001 and the Beyond the Border Agreement of 2011 - in order to analyze in depth the way in which Canada and the United States combined security and trade. In the lens of those two agreements, the functioning of the smart border will be explained in order to better grasp the logic that underlies it as well as to assess its strengths and its weaknesses. Ultimately, we will wonder if Europe can draw lessons from this reconceptualized way of reinforcing borders and, conversely, if North America - and the Smart Border - can be used as an experiment that can be applied in Europe.

\section{The Establishment of the Smart Border}

\subsection{How it Works}

Following the attacks on the World Trade Center and the Pentagon, the Bush administration realized that something had to be done to better manage the northern border - and American borders in general. Indeed, after closing its land borders on September 11, Washington reopened them the very next day, controlling thoroughly every vehicle and screening every person crossing into the country ${ }^{33}$. However, the Bush administration soon realized that the situation was not sustainable and that, if they went on this way, the American economy would be hit badly, indirectly allowing terrorists to reach their goal: hurting the US in one way or another. Therefore they decided to find a compromise in order to securitize borders without crippling cross-border flows and thus impacting the American economy ${ }^{34}$. As then Customs Commissioner Robert Bonner said: “On 9/12, I realized we had to find ways to secure our border, but to do so without shutting it down - without shutting down our economy in the process ${ }^{35}$ ". To do so, they had to come up with a new kind of border that would act alongside those two goals, security and facilitation, or access: "neither high barriers nor open bridges would do. The new border ha[s] to be marked by a unique kind of fence ${ }^{36,}$.

\footnotetext{
${ }^{33}$ Bonner, Robert C.. "Remarks by Robert C. Bonner Canadian/American Border Trade Alliance Washington, D.C.", $\quad$ December 9, 2005, <http://www.cbp.gov/xp/cgov/newsroom/speeches_statements/archives/2005/09122005_speech.xmlg> (accessed on November 6, 2008).

${ }^{34}$ Bonner, Robert C., Border Security Challenges After 9-11-3 Commissioners of US CBP, Washington DC, US Customs and Border Protection, 2011, <http://www.cbp.gov/xp/cgov/newsroom/highlights/sec_chal.xml> (accessed on September 16, 2011).

${ }^{35}$ Bonner, Robert C., 2005, op. cit..

${ }^{36}$ Pauly, Louis, "Canada in a New North America" in Peter Andreas The Rebordering of North America: Integration and Exclusion in a New Security Context, New York, Routledge, 2003, p. 93.
} 
Finding this unique kind of border meant reconceptualizing border security and, more specifically, reconceptualizing how a border works. Traditionally, borders are apprehended in a linear way and rethinking border security meant rethinking this approach or, as the Conference Board of Canada recommended in 2001 "moving from the Maginot Line to in-depth security ${ }^{37 \text { ". }}$ This was done through the Smart Border Declaration, a bilateral action plan signed by the United States and Canada on December 12, 2001, whose goal was to approach security and economic prosperity as two mutually non-exclusive goals. Built on four "pillars" - "the secure flow of people, "the secure flow of goods", "secure infrastructure" and "coordination and information sharing" - this document contained 33 measures that transformed the Canada/US border from within ${ }^{38}$.

The uniqueness of the "border of the future ${ }^{39}$ " was to be found in the principles that underlay the enterprise and that reconceptualized the way borders function. The first one was the segmentation of flows ${ }^{40}$. The idea was to separate high-risk and unknown individuals and goods from low-risk individuals and goods in order to speed up the crossing of the latter category in order to focus on the former category. Instead of treating every person and container in the same way - the way borders had traditionally worked so far - the border now started differentiating known and unknown users. In other words, the smart border became a filter that "sorts flows out $^{41}$ ". This was done through the creation of facilitation programs (3) - trusted travelers and trusted trader programs ${ }^{42}$. With NEXUS, for instance, people would go through a background check in order to prove that they did not represent a risk to national security. Once cleared, they became members of the program, were granted a NEXUS card and could cross at dedicated lanes more quickly than regular people $\mathrm{e}^{43}$.

\footnotetext{
${ }^{37}$ Shea, Andrew. Border Choices: Balancing the Need for Security and Trade, Ottawa, Conference Board of Canada, 2001, p. 2.

${ }^{38}$ The Canada-U.S. Smart Border Declaration. Ottawa, Department of Foreign Affairs and International Trade, 2001, <http://www.dfait-maeci.gc.ca/anti-terrorism/declaration-en.asp> (consulté le 2 avril 2012).

${ }^{39}$ This expression was first used by Tom Ridge, who was at the head of the Office of Homeland Security and then used again by George W. Bush (quote by Alden, 2011, op. cit. p. 137)

${ }^{40}$ Bersin, Alan, "Lines and Flows: the Beginning and End of Borders", in Brooklyn Journal of International Law, Vol. 37, Issue 2, 2012, pp. 401-402.

${ }^{41}$ Amilhat-Szary, Anne-Laure, Qu'est-ce qu'une frontière aujourdhui?, Paris , PUF, 2015, p. 30.

${ }^{42}$ DFAIT, 2011, op. cit..

${ }^{43}$ A similar program was put in place for goods: the Free and Secure Trade (FAST) program (Canada, Border Services Agency, «About NEXUS», Ottawa, Canada Border Services Agency, <www.cbsaasfc.gc.ca/prog/nexus/about-sujet-eng.html> (consulté le 17 avril 2012)).
} 
The second principle that changed in depth the way the border worked was what would be later defined as a "layered approach to security ${ }^{44 "}$. The goal was to think of the border no longer as the first line of defense but as the last line [Holland, 2010, 1] - an approach that was at cross purposes with how borders were traditionally comprehended. To do so, Canada and the United States moved some controls away from the border thus trying to detect threats as early as possible. This was done through air preclearance (7) and land preclearance ${ }^{45}$ (15): border controls - documentation checks, questions, and so on... - were to be inverted. They would be performed before people crossed the border - on the Canadian side by US border officers and vice versa. Another example was the deployment of immigration officers overseas (12) in foreign ports to control goods before they reached North America or the creation of Advance Passenger Information / Passenger Name Record (8) that required airplane companies to provide personal information about their passengers - name, citizenship, date of birth and so on ${ }^{46} \ldots$

The third principle that led to a mutation of the border was integration. This concept led to the merger of some programs that were to launch security across the border in a bilateral way and no longer just along the border in a traditional way. Also known as "perpendicular securitization $^{47 "}$ or "in-depth security ${ }^{48,}$, the approach was meant the make to border a bilateral enterprise, with programs such as Visa Policy Coordination (6), Integrated Border and Marine Enforcement Teams (23), Joint Enforcement Coordination (24), Integrated Intelligence (25), Joint Training and Exercises $(30)^{49}$. To illustrate this principle, the Shiprider program is maybe the most telling example. Part of the measure entitled "Integrated Border and Marine Enforcement Teams" (23), it was meant to bring together Canadian and American lawenforcement agencies in order to patrol lakes and rivers together, thus giving them the jurisdiction to cross the border in order to chase after potential criminals $\mathrm{s}^{50}$.

\footnotetext{
${ }^{44}$ Frontline, Technology, the Future of Border Security, Washington, US Customs and Border Protection, 2008, p. 20.

${ }^{45}$ Only air pre-clearance was put in place in the wake of 9/11. Land pre-clearance was however not put in place until recently because of legal issues.

${ }^{46}$ Department of Foreign Affairs and International Trade, The Canada-US Smart Border Declaration, Ministère des Affaires Etrangères et du Commerce International, 2001, <ttp://www.dfait-maeci.gc.ca/anti-terrorism/actionplanen.asp> (accessed on February 15, 2007).

${ }^{47}$ Beylier, Pierre-Alexandre, Canada/Etats-Unis: les enjeux d'une frontière, Rennes, Presses Universitaires de Rennes, 2016.

${ }^{48}$ Shea, Andrew, 2001, op. cit., p.2

${ }^{49}$ DFAIT, 2001, op . cit.

${ }^{50}$ Beylier Pierre-Alexandre, 2016, op. cit., pp. 48-49.
} 
Hinging on those three new principles, the smart border conveyed a new vision and a new way of functioning that were both carried out through the implementation of concrete measures. The result was therefore a hybrid border that not only saw the Canada/US border re-functionalize after decades of being the "longest undefended border in the world" but also meant the

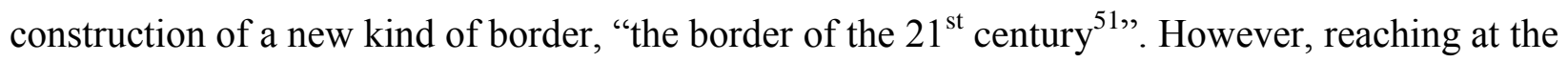
same time security and prosperity was no easy task and the smart border, though working very well on paper, soon encountered problems when it was put in place.

\subsection{The Problems of the Smart Border: a Dysfunctional Border}

The first area that was impacted by the measures put in place after 9/11 was cross-border trade. A number of researchers have tried, over the years, to quantify the impact that those measures have had on exports and imports and they have determined a correlation between a decrease in trade and the re-functionalization of the Canada/US border ${ }^{52}$. It is especially the case for Canadian exports to the United States that were $26 \%$ below the levels that could have been expected if $9 / 11$ had not occurred until $2003^{53}$. But more importantly, the decline remained until $2007-37 \%$ below the levels that could have been expected ${ }^{54}$. This study is not the only one that points out a direct link between the security measures and the decline in bilateral trade. Patrick Grady evaluates the decline at $12,5 \%$ below expected levels ${ }^{55}$. Even if the numbers vary from one study to the next, Canadian exports were impacted by the re-functionalization of the border to a certain extent and this represents a loss that oscillates between 25 and 40 billion dollars a year depending on the study ${ }^{56}$. It is worth noting, however, that the impact was asymmetrical and US exports did not decline in the same way. As far as they are concerned, the decline was only

\footnotetext{
${ }^{51}$ DFAIT, 2001, op. cit..

52 The methodology that was used was a statistical formula the goal of which was to isolate the degree of responsibility of security measures from other factors such as the exchange rate, the inflation rate, economic problems, and so on...

${ }^{53}$ Globerman, Stephen and Storer Paul, The Impact of 9/11 on Canada-US Trade, Bellingham, Washington, Border Policy Research Institute, Western Washington University, 2006, p. 5.

${ }^{54}$ Globerman, Stephen and Storer Paul, "Border Security and Canadian Exports to the United States: Evidence and Policy Implication”, in Canadian Public Policy - Analyse de Politiques, Vol. XXXV, n², 2009, pp 182-183, Montreal, University of Toronto Press, pp. 182-183.

${ }^{55}$ Grady, Patrick, "Were Canadian Exports to the U.S. Curtailed by the Post-9/11 Thickening of the U.S. Border?", Global Economics Ltd, 2009), p. 9.

${ }^{56}$ Ibid, p. 13 and Globerman, Stephen and Storer Paul, 2009, op. cit., p. 184.
} 
temporary between 2002 and 2003, and it then subsided in 2004 before completely disappearing after $2005^{57}$.

The second consequence of the post 9/11 security policy was the fact that the border has become more and more expensive to cross. Between new requirements such as the e-manifest that demands that companies send more and more data to border agencies 24 hours before crossing the border ${ }^{58}$, border wait times that have a particularly negative consequence for the transportation sector ${ }^{59}$, or even facilitation programs that have forced companies to secure their supply chain ${ }^{60}$, companies involved in cross-border trade have found it more and more expensive to do business with the other country.

The corollary to this is the fact the border has lost its flexibility. Longer wait times were common at some point - in 2002 or 2007 and its "summer of hell" that saw wait times to cross the border skyrocket to 2 to 3 hours ${ }^{61}$ - but they no longer are. What has become problematic is the absence of a general rule. It can take you 10 minutes to cross the border or two hours ${ }^{62}$. This unpredictability has deeply impacted the way companies do business across the border. Companies used to base their production on "just-in-time" delivery cutting stocks and inventories in order to maximize profits. But, in the years following $9 / 11$, they could no longer do that and they acted following a "just-in-case" approach ${ }^{63}$ - sending shipments in advance, stockpiling inventories, giving more time to ship goods, using smaller ports of entry. Basically, they had to go back to pre-free-trade practices that had been abandoned since the 1980's and that were less profitable ${ }^{64}$. For the sectors that had integrated their supply chains across the border, on the basis of an open, flexible and predictable border, such as the auto industry and the agro sector, the refunctionlization of the border jeopardized their production system and led to a restructuration of it that amounted to a return to the past.

\footnotetext{
${ }^{57}$ Globerman, Stephen and Storer Paul, 2006, op. cit., p. 9.

${ }^{58}$ Canadian Chamber of Commerce, Finding the Balance: Shared Border of the Future, Ottawa, Canadian Chamber of Commerce, 2009, pp. 6-7.

${ }^{59}$ Transport Canada, The Cumulative Impact of US Imports Compliance Programs at the Canada/US Land Border on the Canadian Trucking Industry, Ottawa, Transport Canada, 2005, p. 35.

${ }^{60}$ Furia, Peter et al. «Customs-Trade Partner Against Terrorism », Charlottesville, University of Virginia, Center for Survey Research, 2011, pp. 5-8.

${ }^{61}$ Alden, Edward, 2008, op. cit., p. 282.

62 Anderson, Bill, The Border and the Ontario Economy, Windsor, Cross-Border Transportation Center, Windsor University, <http://www.uwindsor.ca/crossborder/system/files/Report_The_Border.pdf> (Accessed on October 18, 2012), pp. 21-22.

${ }^{63}$ Godfarb, Danielle, Is Just-In-Case Replacing Just-in-Time? How Cross-Border Trading Behavior Has Changed Since 9-11, Ottawa, Ontario, Conference Board of Canada, 2007, pp. 3-6.

${ }^{64}$ Ibid.
} 
Finally, the second area that was impacted by the new security paradigm was travelers but again, not every category was impacted in the same way. First of all, Canadian tourists ${ }^{65}$ experienced a very slight 3.5\% decrease from 14.4 million in 2000 to 13.9 million in 2004 before increasing again, exceeding pre-9/11 levels (fig 1.a). The category that was hit badly was that of Canadian excursionists. Even if they had begun to fall before 9/11, the terrorist attacks further contributed to this decline - from 28 million in 2000 to 24 million in 2008, with a 21,4 million low in 2003 (fig 1.b) ${ }^{66}$. As far as Americans are concerned, the statistics are even more telling. American tourists declined from 16.1 million but only after an all-time high in 2002 to 11.6 million in 2009 - a 28\% drop (fig 1.c). However, the numbers remained at this level until 2014 and have never gone up again ${ }^{67}$. Finally, the category that has been impacted the most is that of American excursionists. They were 28.8 million Americans to cross the border for a same-day travel in 2000 and only 8.8 million still did it in 2014 - a $71 \%$ decrease in 14 years (fig 1.d) ${ }^{68}$. Not everyone was impacted in the same way but as far as Americans tourists and excursionists are concerned, there is a direct correlation between the terrorist attacks, the subsequent security policy and the fact that they no longer crossed the Canada/US border. Yet, beyond just absolute numbers, what is interesting to notice is that some kind of reconfiguration occurred. In 2000, $60 \%$ of American travels were same-day travels (excursionists) whereas $43 \%$ of travels exceeded 24 hours (tourists) ${ }^{69}$. This change in terms of proportions show that Americans rather cross the border now for a longer period of time and no longer for the day. It shows that fact that the "amateur border" lost its influence: indeed it was customary for Americans to go to Canada to shop, to eat at a restaurant, to attend a hockey game and so on... It has become less and less the case $^{70}$.

\footnotetext{
${ }^{65}$ This terminology has been borrowed from Marie Carmen Macia (cf. Macias, Marie-Carmen. «L'Espace frontalier Mexique/Etats-Unis après le 11 septembre 2001 -Entre processus transfrontalier et transnationaux », Cahiers des Amériques latines $\mathrm{N}^{\circ} 56,2007 / 3$, p. 83-98).

${ }^{66}$ NATS, 2016, op. cit.

${ }^{67}$ Ibid.

${ }^{68}$ Ibid.

${ }^{69}$ Ibid.

${ }^{70}$ Sands, Christopher, Toward a New Frontier: Improving the U.S.-Canadian Border, Brookings, Metropolitan Policy Program, 2009, p. 26.
} 

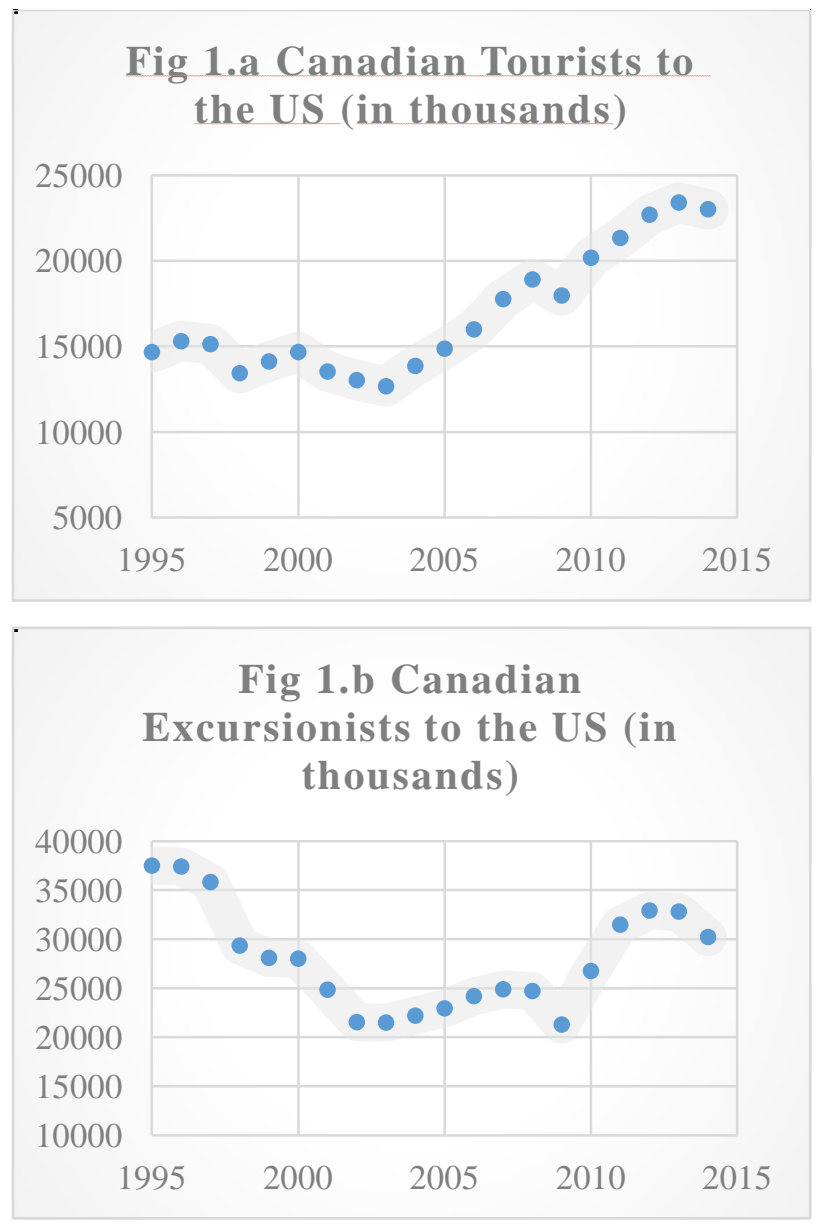

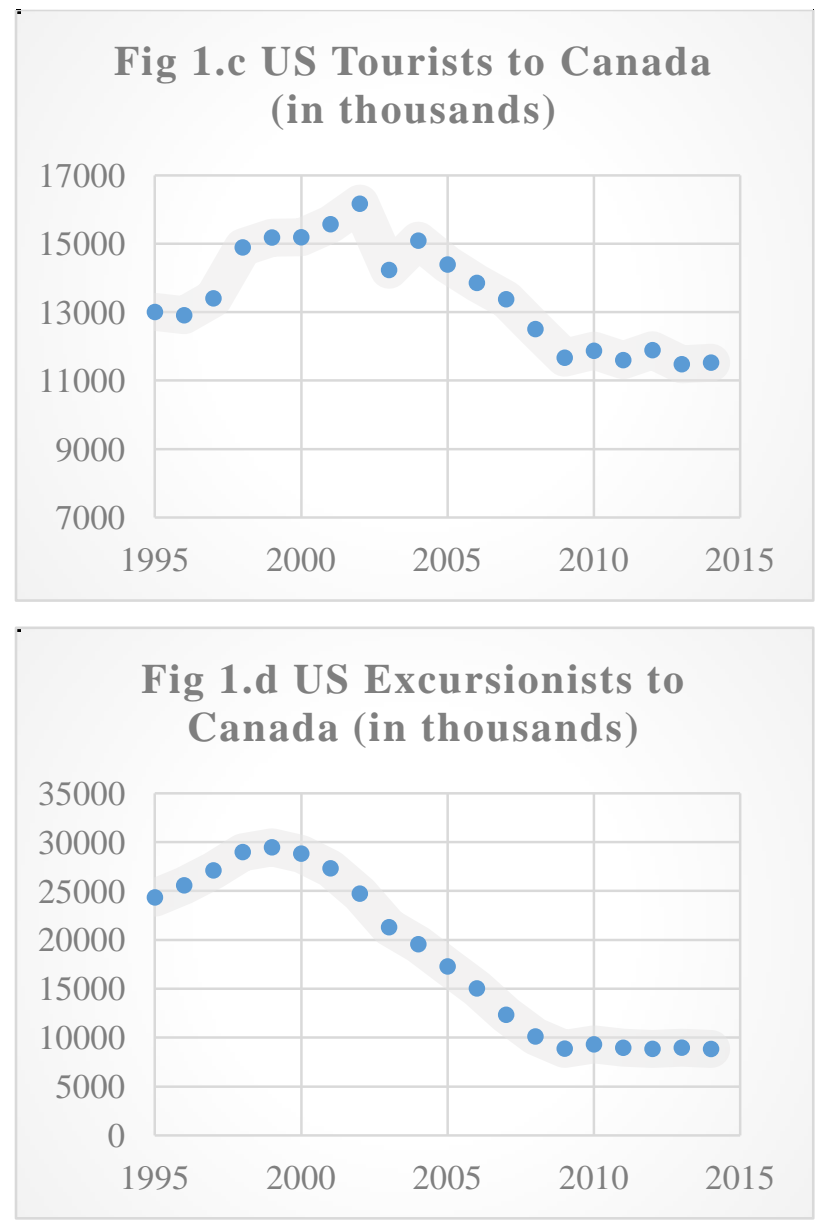

Source: NATC, 2016

In all, in spite of the efforts, the smart border failed to balance security and facilitation. Although the impact was not identical for each country and for each sector or category of people, the "new border" created an obstacle to cross-border trade and travel. It became an "invisible wall ${ }^{71}$ ". But more importantly than that, its perception changed after $9 / 11$ from an "administrative inconvenience" to "a real border" to paraphrase former US Secretary of Homeland Security Janet Napolitano ${ }^{72}$. Some measures, such as the Western Hemisphere Travel Initiative that required people to show a passport or another biometric identification document to cross the border, as of June 2009, were perceived as a "hassle ${ }^{73}$ ". The refunctionalization of the

\footnotetext{
${ }^{71}$ Interview with Mark Holland, Member of Parliament for Ajax - Pickering, Ontario, Liberal Critique for Public Safety, Ottawa, March 10, 2010.

${ }^{72}$ Quoted by Alberts, Sheldon "US Stays Firm on Border-Security Deadline Security chief opposes bill to Delay Strict Passport Rules", Ottawa Citizen, March 26, 2009.

${ }_{73}$ Leahy, quoted by the Associated Press, "U.S. Congress Votes to Stall Passport Rules Till mid-2009”, The Toronto Star, December 21, 2007.
} 
border made it more aggressive, more obstructive, thus building a psychological barrier between

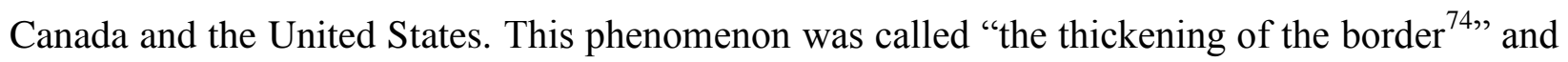
was at cross purposes with what the Smart Border should have been.

As a consequence, for an entire decade, several interest groups published reports in order to point out the problems that the "smart border" was facing such as Finding the Balance, Towards a New Border published by Canada's Chamber of Commerce. Their goal was to lobby the Canadian and the American governments and to force them to act and to make the border less dysfunctional. Eventually that is what Ottawa and Washington agreed to do when they signed the Beyond the Border Agreement in February 2011.

\section{2. "Fixing" the Canada/US border: the Beyond the Border Agreement}

\subsection{The Agreement}

When it was rumored that Canada and the United States were negotiating a border agreement, some analysts started saying that the two North American neighbors intended to put in place some kind of European-like security perimeter ${ }^{75}$. Others implied it would entail "the most sweeping changes to the Canada-U.S. border since the 1988 free-trade agreement ${ }^{76, "}$.

The framework agreement was signed on February 4, 2011 but it was not until December 2011 that the contents of the agreement were made public. As it turned out, the final result was not as far-reaching as some people had expected. It was not a treaty, it was just, like the Smart Border Declaration, an action plan, a series of "concrete" measures aiming at "thinning a thickening border ${ }^{77}$ ". Yet, it was very much welcome by the business sector: "an important step forward in Canada-U.S. relations", for the Canadian Council of Chief Executives" ${ }^{78}$, "an

\footnotetext{
${ }^{74}$ This expression was first used by then Canadian ambassador to the United States, Michael Wilson in order to refer to the dysfunctional problems that the Canada/US border was facing because: "We call it a thickening of the border" (cf. "Trade, Travel Problems at Border Rankle Canada", <http://www.canada.com/victoriatimescolonist/news/story.html?id=b1f573d2-0a11-4b19-84fd-cfa412cf58bb> (consulté le 19 octobre 2012)).

${ }^{75}$ Potter, Mitch, "Canada Warms to Idea of a Tougher 'Perimeter'”, Toronto Star, December 27, 2009.

${ }^{76}$ Ibbitson, John and Chase, Stephen (a), "Harper and Obama Eye Sweeping Change in Border Security", The Globe and Mail, February 2, 2011.

${ }^{77}$ Travers, James, "Canadian Concessions More Certain Than Open U.S. Border”, Toronto Star, February 11, 2011.

${ }^{78}$ Manley, John, "Stronger Canada-U.S. Partnership Will Strengthen Economy and Promote Job Creation, CEOs Say", Ottawa, Canadian Council of Chief Executives, February 4, 2011, <http://www.ceocouncil.ca/en/view/?area_id=1\&document_id=1440> (accessed on February 5, 2011).
} 
ambitious gesture", for Canada's Chamber of Commerce that saw in it "a more modern and effective border policy ${ }^{79}$,"

Organized around five objectives - "Addressing threat early", "Trade facilitation, economic growth and jobs", "Cross-border law enforcement" and "Critical infrastructure and cybersecurity" - the agreement hinges on groundbreaking principles, just like the Smart Border

\section{Declaration.}

In the continuity of its twin agreement, Beyond the Border, as it is known, puts forward the principle of moving controls away from the border in order to detect potential threats as early as possible ${ }^{80}$. But the two governments take this principle to the next level through more harmonized controls in order to avoid the "duplication of controls 81 ". The idea is to follow the motto "cleared once accepted twice" and to reinforce "perimeter security". Contrary to what some people had anticipated or even feared, the agreement did not lead to the implementation of an actual continental perimeter but rather to a "theoretical perimeter ${ }^{82 "}$. Indeed, the goal is to harmonize measures or programs and to move them to the perimeter whenever it is possible, without compromising the security system of either country ${ }^{83}$. Several initiatives have enabled Canada and the United States to put this principle into practice through, for instance, the collection of advance information, or the "harmonized approach to screening inbound cargo arriving from offshore ${ }^{84,}$, and more generally "us[ing] a common approach to screening methodologies and programs ${ }^{85}$. Another example can be the Electronic Travel Authorization that illustrates the "common approach to screening travelers" that the two partners want to put in place $^{86}$. In order to gain more flexibility, the action plan also proposed the harmonization of

\footnotetext{
${ }^{79}$ Beatty, Perrin, "A Shared Vision for Perimeter Security and Competitiveness: a Step in the Right Direction", Ottawa, Chambre de Commerce du Canada, February 4, $2011<$ http://www.chamber.ca/index.php/en/mediacentre/C197/a-shared-vision-for-perimeter-security-and-competitiveness-a-step-in-the-ri/> (accessed on February 5, 2011).

${ }^{80}$ Government of Canada, Perimeter Security and Economic Competitiveness - Action Plan, Ottawa, Government of Canada, 2011, https://www.publicsafety.gc.ca/cnt/brdr-strtgs/bynd-th-brdr/ctn-pln-en.aspx (accessed on August 12, 2017), p. 4.

${ }^{81}$ Ibid, p. 5.

${ }^{82}$ Interview with Simon Kennedy, Deputy Minister, Industry Canada, Chair of the Beyond the Border Working Group, Ottawa, October 13, 2011.

${ }^{83}$ Ibid.

${ }^{84}$ This would be done through "Mutual recognition of air cargo", "Developing a common set of required data elements for all modes of transport for advance security screening of cargo" and "developing an Integrated Cargo Security Strategy $[\ldots]$ to address risks associated with shipments arriving from offshore based on informed risk management" (Governement of Canada, 2011, op. cit. pp. 6-7).

${ }^{85}$ Ibid, p. 9.

${ }^{86} \mathrm{Ibid}$, p. 10.
} 
some facilitation programs - e.g. Partners in Protection and C-TPAT - thus allowing companies to apply to both programs at the same time ${ }^{87}$. Finally, after several failed attempts, they also decided to implement land preclearance to better take advantage of "inverted controls" 88 ".

The corollary to this first principle of harmonization is that of integration. Although it was already present in the Smart Border Declaration it was never really developed - in part because the US deployed a number of unilateral measures that clashed with the objective of the agreement in terms of cooperation ${ }^{89}$. Therefore Beyond the Border restated its commitment to security integration through some emblematic measures. For instance it was decided to build on the Shiprider program in order to expand joint patrols to the land border ${ }^{90}$. Canada and the United States also decided to deploy new technology to "mutually recognize passenger baggage screening ${ }^{91 "}$. Finally, one last example could be the long awaited "entry and exit information system" so that the entry information to one country could be used as the exit information to the other country. This measure required extensive integration between the two countries in terms of data and information sharing ${ }^{92}$.

Finally, the last principle that was also present in the 2001 agreement is the segmentation of flows, using the border as a filter that separates cross-border flows. The idea is to build on existing facilitation programs and to "enhance" them in order to make them more efficient. Indeed, the problem is not the fact that they do not work, the issue is rather the fact that they are no used by enough people ${ }^{93}$. The agreement thus commits both governments to selling them to companies and people in order to enroll as many people as possible, but also to building more dedicate lanes, especially for NEXUS, in order to make their crossing more fluid ${ }^{94}$. In addition to building dedicated lanes, the action plan also intends to deploy Radio Frequency Identification RFID technology in order to "facilitate secure passage and expedite processing 95 ".

\footnotetext{
${ }^{87}$ They also decided to align Canada's Customs Self-Assessment and the United States' Importer Self-Assessment programs (Ibid, 14).

${ }^{88}$ Ibid, p. 16.

${ }^{89}$ Beylier, Pierre-Alexandre, «Le Programme Shiprider», in Contrôle et sécurisation des zones frontalières Pratiques et discours en France et au Canada (sous la direction de Jean-Valéry Lettermann et Eric Tabuteau), Paris, Michel Houdiard, 2015, pp. 44-55.

${ }^{90}$ Governement of Canada, 2011, op. cit. p. 25.

${ }^{91}$ Ibid, p. 8.

${ }^{92}$ Ibid, p. 11.

${ }^{93}$ Interview with Simon Kennedy op. cit. .

${ }^{94}$ Governement of Canada, 2011, op. cit. p. 13.

${ }^{95}$ Ibid, p. 18.
} 
Ultimately the goal is not to erase the border per se but to lessen the pressure that has increased on the international line since 9/11, by moving some controls away from the border and thus reinforcing perimeter security ${ }^{96}$. More importantly than that, in Beyond the Border, we can identify the same key principles - whether moving controls away from the border, promoting integration and cooperation or segmenting flows - as well as the same objectives as in the Smart Border Declaration. As Barack Obama put it in 2011 when the action plan was released, the main goal of the agreement is to strike the right balance between security and facilitation or access: "[t]he [...] agreement merges U.S. and Canadian security concerns with our mutual interest in keeping our border as open as possible to legitimate commerce and travel ${ }^{97}$ ". All this can also be seen in the fact that some programs from the 2001 agreement are either deepened or expanded such as NEXUS, FAST or Shiprider.

All in all, what Beyond the Border does is build on the Smart Border and make it more efficient, more flexible, without compromising security. All in all, it aims at establishing a more accurate balance between security and facilitation by giving it a second lease on life. In other words this new agreement puts in place a new version of the Smart Border, a "Smart Border $2.0^{98,}$.

\subsection{The Stakes of the Agreement}

In terms of conceptualization, this second agreement does not alter the principles put forwards in the Smart Border Declaration. Rather, it retains them and takes them to the next level. Through the notion of perimeter security - a lexical subtlety that aims at reinforcing security at the perimeter when possible and not putting in place a real security perimeter - one finds oneself in the logic of the layered approach to security that was established by the smart border. Basically, Beyond the Border creates and reinforces a new layer, a common line at the continental scale, around the perimeter. The novelty is that the agreement restores trust between

\footnotetext{
${ }^{96}$ Interview with Simon Kennedy op. cit..

97 Obama, Barack, "Statements by President Barack Obama and Prime Minister of Canada Stephen Harper of Canada", Washington DC, White House, December 7, 2011, < http://www.whitehouse.gov/the-pressoffice/2011/12/07/statements-president-barack-obama-and-prime-minister-canada-stephen-harp> (accessed on December 8, 2011).

${ }^{98}$ Beylier, Pierre-Alexandre, 2016, op. cit., p. 321.
} 
the two North American partners ${ }^{99}$ by implying that Canadian controls and security requirement are as effective as US controls ${ }^{100}$.

What really makes Beyond the Border an innovative agreement is the fact that it promotes integration. Again, nothing really new since the 2001 agreement already contained this concept but in a more punctual way. With Beyond the Border, integration is the underlying logic. Through harmonized programs, joint patrols, information sharing, the two countries promote dialogue and cooperation but they also merge some aspects of each country's border security system in order to have a more efficient border. After almost a decade of unilateralism - mostly on the part of the Bush administration - the agreement marks a turning point in Canada/US relations.

It is still difficult to assess the success of the agreement but under Obama, a better balance was stricken between security and facilitation, with more emphasis laid on facilitation. Through this initiative, the facilitation aspect of the smart border could take momentum. For instance, the participation in the NEXUS program that was around 5\% in 2009-2010 more than doubled to $12 \%$ in $2015^{101}$. More importantly, after 2009 and even more so after 2011, a greater number of Canadian tourists and excursionists crossed the border (cf Fig 1.1 and 1.b). After a decade of decrease or stagnation - especially for excursionists - the numbers were up again and went beyond pre-9/11 levels. This was not really the case for American travelers.

\footnotetext{
${ }^{99}$ John Ibbitson (b), "Beyond the Canada/U.S. Border: Open Doors, Baby Steps", The Globe and Mail, July 5, 2011. ${ }^{100}$ Interview with Abdias Ortiz, Western Hemisphere Division Director for International Affairs, US Customs and Border Protection, Washington DC, June 25, 2012.

${ }^{101}$ Public Safety Canada, 2015 Beyond the Border Implementation Report, Ottawa, Public Safety Canada, 2015 $<$ https://www.publicsafety.gc.ca/cnt/rsrcs/pblctns/2015-bynd-brdr-mplmntn/index-en.aspx> (accessed February 15, 2016).
} 
Fig 2 Participants in the NEXUS Program

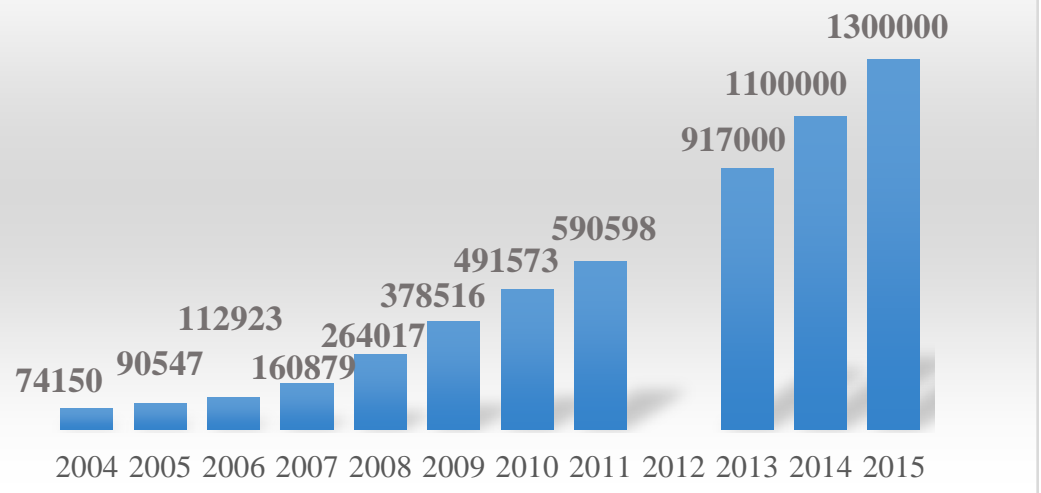

Source : CBSA, 2016

\section{Conclusion}

As a conclusion, combining a border that is at once open and secure is no easy task. Striking the right balance between security and facilitation is not an enterprise that can be reached overnight. Since it alters the traditional functioning of the border, it has been a slow ongoing process, a work in progress. First, the Smart Border Agreement had a hard time reaching its double objectives of securing the border "without impeding the legitimate flow of crossborder trade and travel ${ }^{102 "}$ and because the management of the border was caught between cooperation and unilateralism ${ }^{103}$ the "new border" did impact trade and travel. Second, it took over ten years and two agreements to extensively implement the "new vision" that the smart border represents.

But the most important thing is that the smart border has become a genuine "new border". It has allowed Canada and the United States to put in place a "dilated" border ${ }^{104}$, or to me more accurate, a "reticular border ${ }^{105 "}$ whose controls are no longer performed on the very boundary but away from it, sometimes in distant locations e.g. in the foreign port where the shipment is loaded or in the international airport from where a person is flying. So, the notion of border security has evolved to mean something more than just the controls at designated checkpoints or the surveillance of the international line. Border security takes on new forms through information

\footnotetext{
102 Government of Canada, 2001, op. cit..

${ }^{103}$ Beylier, Pierre-Alexandre, 2016, op. cit., pp. 180-181.

${ }^{104}$ Ibid, p. 450.

${ }^{105}$ Amilhat-Szary, Anne Laure, 2015, op. cit., p. 49.
} 
sharing, new technologies, the collection of data, the securitization of the flows - of people and goods - themselves. The border becomes at once a "virtual wall ${ }^{106 "}$ and a networked series of borders, a system of borders. What also happened with the smart border is the fact that people are treated differently, whether you are a low-risk Canadian businessman or a refugee, the border

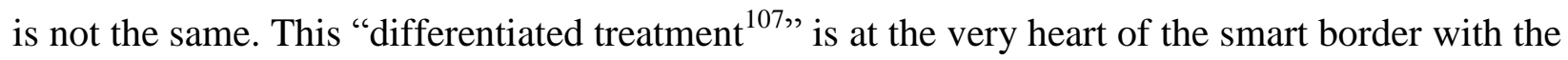
novelty that the facilitation programs constitute. Yet, its impact is even more far-reaching insofar as it is not just the smart border that acts like that but borders in general throughout the world that have been modeled on the smart border. In other words, the "border of the future" put in place after 9/11 has initiated changes in the way borders work, not just in North America, but also on the global stage.

At the moment, the emphasis is laid on facilitation in order to make the whole border system more flexible. However, beyond the measures themselves, what really matters is the political commitment of the governments, which underlies Beyond the Border. And with the new American President, Donald Trump, who wants to renegotiate NAFTA and build a wall, along the US southern border, the Canada/US border seems to be thrown, once again, in an uncertain context. Protectionism and a new approach to border security might as well tip the balance back toward more security and make the border system dysfunctional again.

\section{References}

Alberts, Sheldon "US Stays Firm on Border-Security Deadline Security chief opposes bill to Delay Strict Passport Rules”, Ottawa Citizen, March 26, 2009.

Alden, Edward, The Closing of the American Border, New York, HarperCollins, 2008.

Amilhat-Szary, Anne-Laure, Qu'est-ce qu'une frontière aujourdhui?, Paris , PUF, 2015.

Anderson, Bill, The Border and the Ontario Economy, Windsor, Cross-Border Transportation Center, Windsor University, <http://www.uwindsor.ca/crossborder/system/files/Report_The_Border.pdf> (Accessed on October 18, 012).

Andreas, Peter, The Rebordering of North America: Integration and Exclusion in a New Security Context, New York, Routledge, 2003.

Associated Press, «U.S. Congress Votes to Stall Passport Rules Till mid-2009 », The Toronto Star, December 21, 2007.

\footnotetext{
${ }^{106}$ Interview with Mark Holland, 2010, op. cit..

107 Amilhat-Szary, Anne Laure, 2015, op. cit., p. 28.
} 
Beatty, Perrin, "A Shared Vision for Perimeter Security and Competitiveness: a Step in the Right Direction", Ottawa, Chambre de Commerce du Canada, February 4, 2011 <http://www.chamber.ca/index.php/en/media-centre/C197/a-shared-vision-for-perimetersecurity-and-competitiveness-a-step-in-the-ri/> (accessed on February 5, 2011).

Bersin, Alan, "Lines and Flows: the Beginning and End of Borders", in Brooklyn Journal of International Law, Vol. 37, Issue 2, 2012, pp 389-406.

Beylier, Pierre-Alexandre, Canada/Etats-Unis: les enjeux d'une frontière, Rennes, Presses Universitaires de Rennes, 2016.

Beylier, Pierre-Alexandre, "Le Programme Shiprider», in Contrôle et sécurisation des zones frontalières - Pratiques et discours en France et au Canada (sous la direction de Jean-Valéry Lettermann et Eric Tabuteau), Paris, Michel Houdiard, 2015, pp. 44-55.

Bonner, Robert C.. "Remarks by Robert C. Bonner Canadian/American Border Trade Alliance Washington, D.C.", December 2005, <http://www.cbp.gov/xp/cgov/newsroom/speeches_statements/archives/2005/09122005_speech. xmlg> (accessed on November 6, 2008).

Bonner, Robert C., Border Security Challenges After 9-11 - 3 Commissioners of US CBP, Washington DC, US Customs and Border Protection, 2011, <http://www.cbp.gov/xp/cgov/newsroom/highlights/sec_chal.xml> (accessed on September 16, 2011).

Burleton, Derek, "Canada's Declining Reliance on the US - Where to Grow from Here?", TD Canada, 2012, <http://www.td.com/document/PDF/economics/special/dp0212_trade.pdf> (accessed on September 14, 2012).

Canada Border Services Agency, “About NEXUS”, Ottawa, Canada Border Services Agency, <www.cbsa-asfc.gc.ca/prog/nexus/about-sujet-eng.html> (consulté le 17 avril 2012).

Canadian Chamber of Commerce, Finding the Balance: Shared Border of the Future, Ottawa, Canadian Chamber of Commerce, 2009.

Carroué, Laurent ans Collet, Didier, Canada, Etats-Unis, Mexique - un ancien nouveau monde, Paris, Editions Bréal, 2012.

Clarkson, Stephen, "The View from the Attic", in Peter Andreas, The Rebordering of North America: Integration and Exclusion in a New Security Context, New York, Routledge, 2003.

Clayton, Mark, "Terrorists Aided by a Leaky US-Canada Line", The Christian Science Monitor, September 19, 2001.

Courlet, Claude, "La frontière : couture ou coupure ?", Economie et Humanisme, 1988.

David, Charles-Phillipe, Le 11 Septembre 2001, cinq ans plus tard: Le terrorisme, les Etats-Unis et le Canada, Québec, Septentrion, 2006.

Daniel Drache, Borders Matters: Homeland Security and the Search for North America, Halifax, Fernwood, 2004.

Department of Foreign Affairs and International Trade, "Canada's FDI_stocksOutward_by_Country-FRA", $\quad<$ http://www.international.gc.ca/economist- 
economiste/assets/pdfs/FDI_stocks-Outward_by_Country-FRA.pdf> (accessed on July 13, 2011).

Douzet, Frédéric and Giblin, Béatrice, Des frontières indépassables ?: Des frontières d'État aux frontières urbaines, Paris, Armand, Colin, 2013.

Foucher, Michel, Le Retour des Frontières, Paris, CNRS Editions, 2016.

Foucher Michel., Fronts et Frontières, Paris, Fayard, 1991.

Frontline, Technology, the Future of Border Security, Washington, US Customs and Border Protection, 2008.

Fukuyama, Francis, The End of History and the Last Man, New York City, Free Press, 1992.

Furia, Peter et al. "Customs-Trade Partner Against Terrorism”, Charlottesville, University of Virginia, Center for Survey Research, 2011.

Globerman, Stephen and Storer Paul, The Impact of 9/11 on Canada-US Trade, Bellingham, Washington, Border Policy Research Institute, Western Washington University, 2006.

Globerman, Stephen and Storer Paul, "Border Security and Canadian Exports to the United States: Evidence and Policy Implication", in Canadian Public Policy - Analyse de Politiques, Vol. XXXV, n², 2009, pp 182-183, Montreal, University of Toronto Press.

Godfarb, Danielle, Is Just-In-Case Replacing Just-in-Time? How Cross-Border Trading Behavior Has Changed Since 9-11, Ottawa, Ontario, Conference Board of Canada, 2007.

Gonin, Patrick, «Frontières Impossibles », in Bouquet, Christian and Velasco-Graciet, Hélène, Regards Géopolitiques sur les Frontières, Paris, L'Harmattan, 2007.

Government of Canada, Perimeter Security and Economic Competitiveness - Action Plan, Ottawa, Government of Canada, 2011, https://www.publicsafety.gc.ca/cnt/brdr-strtgs/bynd-thbrdr/ctn-pln-en.aspx (accessed on August 12, 2017)

Grady, Patrick, "Were Canadian Exports to the U.S. Curtailed by the Post-9/11 Thickening of the U.S. Border?", Global Economics Ltd, 2009).

Hart, Gary and Rudman, Warren, Road Map for National Security: Imperative for Change, Washington, United States Commission on National Security/21st Century, 2001.

Ibbitson, John and Chase, Stephen (a), "Harper and Obama Eye Sweeping Change in Border Security", The Globe and Mail, February 2, 2011.

John Ibbitson (b), "Beyond the Canada/U.S. Border: Open Doors, Baby Steps", The Globe and Mail, July 5, 2011.

Konrad ,Victor, "Borders, Bordered Lands and Borderlands: Geographical State of Insecurity between Canada and the United States and the Impacts of Security Primacy" in Vallet Elisabeth, Border, Fences and Walls: State of Insecurity?, New York, Routledge, 2014.

Lybecker, L. Donna, "The Policy of Border Fencing between the United States and Mexico: Permeability and Shifting Fuctions", in The Journal of Southwest, 50, 3 (Autumn 2008), 335352. 
Manley, John, "Stronger Canada-U.S. Partnership Will Strengthen Economy and Promote Job Creation, CEOs Say", Ottawa, Canadian Council of Chief Executives, February 4, 2011, $<$ http://www.ceocouncil.ca/en/view/?area_id=1\&document_id=1440> (accessed on February 5, 2011).

NATC, "Canada/United States Travel by Mode of Transportation", <http://nats.sct.gob.mx/goto-tables/table-9-north-american-passenger-travel/table-9-1b-canada-united-statesunited-statescanada-travel-by-mode-of-transportation/> (accessed on October 12, 2016).

Neff, James et al, "Few Resources Spent Guarding Canada Border", The Seattle Times, September 23, 2001.

Obama, Barack, "Statements by President Barack Obama and Prime Minister of Canada Stephen Harper of Canada", Washington DC, White House, December 7, 2011, $<$ http://www.whitehouse.gov/the-press-office/2011/12/07/statements-president-barack-obamaand-prime-minister-canada-stephen-harp> (accessed on December 8, 2011).

Ohmae, Kenichi, The Borderless World - Power and Strategy in the Global Market Place, New York Coty, Harper and Collins, 1990.

Pauly, Louis, "Canada in a New North America" in Peter Andreas The Rebordering of North America: Integration and Exclusion in a New Security Context, New York, Routledge, 2003.

Potter, Mitch, "Canada Warms to Idea of a Tougher 'Perimeter'”, Toronto Star, December 27, 2009.

Popescu, Gabriel, Bordering and Ordering the Twenty-first Century: Understanding Borders, Plymouth, Rowman and Littlefield Publishers Inc., 2011.

Pradeau, Christian, Jeux et enjeux des frontières, Bordeaux, Presses Universitaires de Bordeaux, 1994.

Sands, Christopher, Toward a New Frontier: Improving the U.S.-Canadian Border, Brookings, Metropolitan Policy Program, 2009.

Shea, Andrew. Border Choices: Balancing the Need for Security and Trade, Ottawa, Conference Board of Canada, 2001.

Statistique Canada, «Tableau 228-0003 - Importations et exportations de marchandises, par groupes principaux et par marchés pour tous les pays », Ottawa, Statistique Canada <http://www5.statcan.gc.ca/cansim/a26> (consulté le 14 mai 2013).

Sloan, Elinor C., Security and Defence in the Terrorist Era: Canada and North America, Montreal, McGill-Queen's University Press, 2005

Transport Canada, The Cumulative Impact of US Imports Compliance Programs at the Canada/US Land Border on the Canadian Trucking Industry, Ottawa, Transport Canada, 2005.

Travers, James, «Canadian Concessions More Certain Than Open U.S. Border», Toronto Star, February 11, 2011.

The Canada-US Smart Border Declaration, Ministère des Affaires Etrangères et du Commerce International, 2001, <ttp://www.dfait-maeci.gc.ca/anti-terrorism/actionplan-en.asp> (accessed on February 15, 2007) 
Valet, Elisabeth, Borders, Fences and Walls - State of Insecurity?, New York, Routledge, 2014, p. 3.

\section{Interviews}

Mark Holland, Member of Parliament for Ajax - Pickering, Ontario, Liberal Critique for Public Safety, Ottawa, March 10, 2010.

Simon Kennedy, Deputy Minister, Industry Canada, Chair of the Beyond the Border Working Group, Ottawa, October 13, 2011.

Abdias Ortiz, Western Hemisphere Division Director for International Affairs, US Customs and Border Protection, Washington DC, June 25, 2012. 